\title{
BEDOUIN WOMEN STATUS UNDER THE PATRIARCHAL SYSTEM IN MIRAL AL TAHAWI'S THE TENT
}

\author{
Zainab Abd Ali Hammood, Lajiman Bin Janoory \\ Department of English language and literature \\ Faculty of languages and communication \\ University Pendidikan of Sultan Idris (UPSI), \\ Tanjung Malim, Perak, Malaysia \\ E-mail: zainab.alhammood@gmail.com
}

Received: 05 April 2019

Accepted: 28 May 2019

\begin{abstract}
This research investigates the status of female characters under the oppressive patriarchal system of Bedouin in the novels of Miral Al Tahawi through the lens of radical feminist theory. Miral Al-Tahawi explains in her novel "The Tent" how women are marginalized and exploited in the context of parental restrictions imposed on them in Bedouin society, which is governed by harsh customs and values. The rationale comes from an understanding of the influence of this patriarchal authority over Bedouin women that reveals the status of women as oppressed and subject to the conditions that control women's identity and limit their freedom. This research will critically analyze the status of women in a gender-focused society. The current study found that Miral al-Tahawi embodied the suffering of Bedouin women through the suffering of the female characters in her novel. She reveals the extent of the suffering and patriarchal oppression that Bedouin women are subjected to in silence.
\end{abstract}

Keywords: women, Patriarchal oppression, Bedoen socity, radical feminism.

\section{Introduction}

This research explores the intention of the Egyptian Bedouin novelist Miral al-Tahawi to explore the Bedouin women under patriarchal oppressive system through the theory of radical feminism, which views that the main reason of women's oppression and marginalization is the patriarchal system. Radical feminists seek to confront patriarchy that marginalizes and exploits women by rearranging society or rearranging the gender roles of the patriarchal system. The radical movement seeks to achieve women's rights and equality with men in all spheres of life (Krps, 1970). In Frederick's view, radical feminism is a movement based on the interest of women's equality and the challenge of sexual discrimination established by the patriarchal system (Frederick, 1992). Although the views of the pioneers of the radical movement, Kate Millett and Marilyn France, are different as for the solutions that can lead to equality of women, they all agree that patriarchy is the root cause of women's oppression, marginalization, and subordination to masculine authority. Millett claims that the main reason for the oppression of women is the patriarchal system (Millet, 1977). Patriarchy treats women as inferior men and treats them as male slaves. Marlene France agrees with this view, arguing that patriarchy is a system that gives men the privileges of power and economic superiority (France, 1983). According to the concept of Radical Feminism, men have the right to take positions in important institutions while 
women are excluded and confined to take care of the family, children, and home. Therefore, according to Radical Feminist, all the reasons for discrimination and marginalization of women can be attributed to the patriarchal oppression they are subjected to under masculine authority. Women are seen as being the other by the patriarchal system and are exploited, dominated and made subordinate by males (Rhodes, 2005). This research examines the female characters in Miral al- Tahawi's novel, The Tent (1996) in light of the radical feminist concepts of the status of Bedouin women under the oppressive patriarchal system.

The importance of the problem in research is that Arab women, especially Bedouin women, suffer silent oppression, where they are subjected to discrimination, marginalization, and denial of rights under a gender-based system. Miral al-Tahawi, through the status of the female characters in her novel The Tent, reveals some of these Bedouin repressive practices that Bedouin women experience and reveals to us the status of Bedouin women under parental authority.

This paper aims at understanding the status of Bedouin women under the patriarchal oppressive system such as Bedouin society. It also aims to portray such oppressive images of women in such a patriarchal society.

\section{Literature Review}

\subsection{Patriarchy}

Patriarchy is a gender system that gives males the privilege to govern and dominate women, while women remain subject to masculine authority. Fatherhood in the traditional sense means the authority of the father or husband over the wife, children and the rest of the family (Bennett, 2006).

\subsection{Radical Feminism}

Radical Feminism is a movement founded on the idea that patriarchy is the main cause of discrimination and oppression of women. The radicalism challenges the patriarchal system by demanding women's equality with men in society. Radicalism believes that the patriarchal system has given stereotypical stereotypes to impose man's dominance and to make women accept their negative roles in society (Millet, 1970).

This research will be studied based on the theory of feminism, which affirms that the patriarchal system is the main reason for the suppression of women and domination by men. Radical feminists seek to change the hierarchical structure of society by changing cultural concepts that make women inferior while giving men all privileges in private and public life. The use of radical theory will enable us to recognize the oppression that women are subjected to under patriarchal repression. Male domination is practiced directly or indirectly against women in the patriarchal system.

Millet believes that patriarchal ideology can be in the form of beliefs applied to a female by male sex such as arranged marriage or a set of rules and provisions that apply to women who are considered irregular of patriarchal rules and laws. (Millet, 1977). Millet also asserts that male domination is a set of ideas that can invade the world by gaining population satisfaction. Sexual politics reinforces male dominance and grants them privileges in all areas while limiting roles of women as a wife, mother and caring for the home. Kate Millett's definition of sexual policy enables women to be aware of their status as the last or lower ones in society, recognize their rights as women, understand patriarchal 
oppression and demand their right to equality with their male counterparts in society (millet, 1970).

Millet believes that males and females occupy different spheres of human activity. Since childhood, sexual identity has been developed through the concepts of culture, character, interests, etc. (Millet, 1977). Therefore, according to Millett, sexual politics has shaped the patterns that should be enjoyed by both sexes by giving women negative qualities such as ignorance, virtue and weakness while men are gifted qualities such as intelligence, strength, and hostility and thus through this classification can make women secure and adhering to weakness and fully subject to the authority of men (Millet, 1970). In this research, radical feminism is applied in the course of understanding sexual politics. In the novel, the status of women can be defined under a patriarchal oppressive system, as in the case of Fatima, the mother, and Safia in the novel.

2.3 Patriarchy in Arab world refers to giving men and old women the authority to dominate and oppress other members of the family. Old women are allowed to take the place of men in controlling other women. (Joseph, 1993). Miral Al Tahawi's The Tent was analyzed from the angle of Radical Feminism. Thus, the analysis of the novel within the framework of Radical Feminism will give a clear picture of understanding the status of Bedouin women in Bedouin patriarchal society through the female characters oppressed in the novel.

\section{Research Method}

The textual content will be analyzed in this qualitative search by translating and deducing texts objectively. Quotations and sentences that explain the oppression of women and their status under the patriarchal system will be the basic material and data for this research. Feminist ideas will be adapted to provide critical reviews that support the radical theory and feminist literature in the status of women under the repressive patriarchal system of Miral Tahawi's novel.

\section{Results and Discussion}

Patriarchal authority is defined as the set of rules and regulations that men establish for controlling and dominating women in political, economic and social spheres. These genderdiscriminatory practices have led women to lose their identity, voice, and denial of their needs in society. Patriarchy also made stereotypes of both sexes. Women are weak and subordinate while wen possesses strength and intelligence. These negative qualities given by the patriarchal system to women make them believe in their powerlessness and surrender to male domination.

Al-Tahawi deals with the above ideas in her novel, The Tent, where female characters are stereotyped as embodiments of negativity, weakness, and obedience, while the male characters are given all the privileges that make them the master of the situation.

\subsection{The oppressed and oppressive model of female: The grandmother}

The patriarchal oppression in this novel is revealed to us by the authority given to the grandmother, who is entrusted with the task of oppressing other women by using the e patriarchal authority because of her old age. According to (Joseph, 1993), in Bedouin communities, male power is delegated to older women to oppress other women on behalf of men. Therefore, we see that the grandmother Hakima, whose name means the ruler, used as a tool to oppress women of the family by patriarchal rules. The grandmother 
Hakimah accepts her role as a submissive woman and as less valuable than men as well as she imposes these ideas and passive roles on other women in her family and order them to be subject:

It was the Grandmother Hakima who was coming in now. She too had the main gate opened for her... was ever different. Was she really a woman? She was the mother of us all. Our great demon mother who wrapped herself in men's scarves... Everyone stood there as she approached the gate (Al Tahawi, 1996:7).

In this quotation, one of her granddaughters, Fatima, describes the moment her grandmother enters the Bedouin house, which looks like a prison where women cannot see outside. Fatima describes her grandmother as being like men in her actions. Fatima wonders: Was she really a woman? This question comes from the masculine image that this grandmother adheres to in order to impose patriarchal rules and values on the women of her family. The grandmother has all the qualities of the Bedouin man, she is harsh and strict and oppresses women around her and prevents them from exercising their freedom and their rights. The grandmother wears the mantle of men and this indicates that she has received the male authority from her absent son to watch his wife and daughters and practices oppression on them. The grandmother in this scene and according to the concept of the radical feminist Kate Millett has accepted the weakness and being as lower value than men. She is considered by the patriarchal system as the other, so the male uses her to impose gender discrimination by making her a tool to oppress other women for his advantages and needs (Millet, 1970).

In addition, the patriarchal society considers that the birth of a female is a calamity or a disaster for the family, since females represent the least valuable members of the society, and their presence can cause the family's reputation to be destroyed or disgraced: "My God, You're a wretched bunch! God has sorely tried your father and he's been patient."(Al Tahawi, 1996:.9).

In this text, the grandmother scorns her son's daughters because she believes that she is abhorrent to her son since the girls in the Bedouin society are considered to be an additional burden to the family and do not add any privileges to the family. The grandmother's words come here, because of the patriarchal background, she has raised, which taught her that the status of power in the patriarchal Bedouin society is male, but women regard themselves as the other. This confirms that the sexual policy that Kate Millett has spoken about, is applied to Bedouin women by the masculine authority. Women in the Bedouin community are marginalized and fully subordinate to parental authority.

Egyptian Bedouin writer Miral al-Tahawi continues to show us the harshness of the patriarchal system in Bedouin society over women. Women in the Bedouin Bedouin community are viewed as a disaster for the family by the community, so families that do not own girls or have a few girls are lucky from the point of view of Bedouin society. The birth of a daughter in a patriarchal society means that she will remain under surveillance for the rest of her life, and the family will subject her to intense surveillance so as not to bring shame or shame in the honor of the family:

I've always said my prayers and not one of them survived. And what a struggle it is from the day they come striking into the world until the Lord takes them away. Look at my son. God has sorely tested him, but he's managed to remain patient(Al Tahawi, 1996: 60). 
In this statement, Al Tahawi reveals to us the Bedouin patriarchal mentality through the grandmother, Hakima, who raised on and absorbed the Bedouin patriarchal values and customs that set her as the "other" or inferior to men. The grandmother Hakimah speaks happily because all her daughters have died, and she thanks the Lord for having taken them before they grow up and bring disgrace to the family. She considers their presence in life as a struggle for her, because the presence of girls in Bedouin society represents weakness and a threat to honor for that family: "And what a struggle it is from the day they come striking into the world until the Lord takes them away" $(p, 60)$.

The grandmother Hakima is a model for the Bedouin woman who is stereotyped by the patriarchal society to make her an oppressive tool against other women. The patriarchal society distributes the roles of both sexes. For the grandmother, she absorbed her negative role, which she has nurtured since childhood, as less valuable and that man is the main focus of the society. The grandmother Hakimah, scolding her son's luck because he has only daughters and no male son. She remembers that God has afflicted her son with daughters and that her son is still patient with that scourge.

We can conclude that Miral Al Tahawi embodies through the grandmother a model of the Bedouin woman who is molded through the patriarchal society to make them satisfied with the rules and provisions imposed by the masculine authority in that community. The grandmother Hakimah is a Bedouin woman who accepts the negative roles given to her by the masculine authority and convinced that she is inferior or less valuable than men. Males in patriarchal society seek to subjugate women to achieve their goals and needs and to extend their authority on women as well as dominate and control them. This is evident through the character of the grandmother Hakima, who represents a real embodiment of the image of subordinate Bedouin women who have been prepared to accept their negative roles in society and to act in favor of masculine authority as a tool to oppress other women.

\subsection{Oppressed Women}

\subsubsection{The daughters (Fatima and Safyia)}

The daughters as Bedouin women in this novel are embodied by the characters Fatima, the elder sister, Safia. Al-Tahawi reveals the status of Bedouin Women in the patriarchal oppressive Bedouin system through the suffering of the subordinate and oppressed female characters in the novel.

In the Bedouin patriarchal society, women are treated as trivial things. They are deprived of many things they wish to do that may violate Bedouin rules and values. The girls live in a state of humiliation and obedience to patriarchal values and their presence in the Bedouin home as a kind of burden and constant concern for the family for fear of causing the destruction of the reputation of the family. Therefore, Bedouin families are keen to keep girls away from everything that may make them rebels against those values, even if it was a song:

You filthy thing, you earthworm! When will you wash your faces with some shame?... you! You little whore, hurry up before I take my shoe off in your open gob."(Al Tahawi, 1996:29).

Here, al-Tahawi gives us a picture of the oppression of women in Bedouin society, where the grandmother reprimands the girls because they wait for her absence to practice singing. When the grandmother returns, she finds the girls singing and starts to insult them because singing and raising the voice, according to Bedouin tradition is forbidden to women. 
The girls are waiting for the grandmother's absence because they know that the grandmother is a tool to execute the masculine rules for women in the absence of her son "the father", therefore, her absence means more freedom them and to and enjoy their time. Al-Tahawi reveals how oppression has been inflicted on Bedouin women since childhood, by setting a series of values, customs, and prohibitions that girls should follow and used to as natural.

One of the things that the Bedouin patriarchal society is keen to uphold and impose on women is to isolate girls from the outside world and prevent them from mixing with men strictly. This is embodied by Al-Tahawi through the female characters confined inside the house with strict rules and values. The exit of women outside the house is a serious matter, women will be punished for and are considered a disgrace to the Bedouin family.

I wasn't paying much attention to what was happening. The important thing was that the main gate was left wide open (Al Tahawi, 1996: 30).

Fatima tells us through this text how she is prevented from seeing behind the walls of the house as part of Bedouin tradition. In Bedouin society, only men are allowed to go out and mix with others, while women are trapped in the house. Fatima as a Bedouin girl, the Bedouin patriarchal laws are applied to her to understand and absorb her negative role in Bedouin society as a source of weakness and a reason to destroy the reputation of the family. Here, Fatima wants to see what is outside the walls of the house. She explains how she does not care about the arrival of the seller of fabrics and jewels to the house as much as the gate was opened and she can see the scenery outside the house.

Under the patriarchal Bedouin system applied to female characters in the novel, women's characters are suffering and trying to rebel, but the size of the restrictions is always greater than their attempts. Women are often weak under patriarchal values in Bedouin society. Fatima continues to look for a way out of the Bedouin rule to get out and see the house:

She's a damned nuisance, climbing up the walls till she cripples herself... only one leg. By God, I'd break your other leg if it would teach you some sham, damn you(AL Tahawi, 1996: 32).

Fatima fails to find a way out to see the outside world she is deprived of. She tries to climb a tree, but she falls and loses her foot. Al-Tahawi makes Fatima's status as evidence of the inferior status of Bedouin women under patriarchal values. In the text above. The grandmother tells her son after his return that his daughter tried to climb the tree to see what is out of the house or to run away. Her conversation with her son comes to confirm the ascendancy and strength of Bedouin patriarchal rulings on women and how women are treated as prisoners who try to escape their restrictions. The grandmother threatens Fatima that she will be severely punished if she tries to escape again.

The grain is ripe, and those filthy peasants, they would steal the kohl

from your eyes. And those girls that you brought into the world to

torment me, someone came to ask for them while you were away

hiding in the mountains (Al Tahawi, 1996: 34).

The status of Bedouin women in marriage and choosing their partner is no better than being imprisoned in the home. Through the words of the grandmother above, Tahawi reveals to us how girls in the Bedouin community of patriarchy are subjected to the will of their entire family in terms of marriage. The grandmother tells her son that his daughters" filthy peasant" are mature and they steal the kohl from his eye, that is, they understand everything and may cause to bring shame on him. She tells him that it is time for marriage 
because there is someone who wants to marry them. She describes them as "filthy peasant" to reduce their importance and because she recognizes that they are a lower value than male according to the values she has grown up on. Women do not have the choice to choose a husband or the right to refuse or accept. Marriage as a decision is in the hands of the family.

Al-Tahawi explains how the identity of Bedouin women is violated as an insulted member of the family that must be disposed of as soon as possible through the words of the grandmother with her son:

Bind them in chains of iron, and throw them into a kind man's house.

By God, a house with all these calamities in it is an evil omen. Put the dusty bird to flight and then God will give you a son to succeed you, my son. Bury them, before they bury your reputation and your fine qualities (Al Tahawi, 1996: 34).

The grandmother continues to talk to her son, calling the girls as" calamities" and insists that their existence is an evil omen within the Bedouin house. She tells him that the girl should be married since the best place for a girl is her husband's house, which is considered a better prison than her presence in her father's house. They have to be restricted by an iron, and this symbolizes the husband's grip on his wife which is just like the grip of the iron, where she will be in his house like a prisoner who is subordinate and obedient. The grandmother concludes that the presence of the male will raise the value of the family and that daughters presence at home may cause a disgrace to the family.

Safia is forced to marry her cousin who is not interested to see her: "I don't want to get married or to paint my hands and feet with henna." (Al Tahawi, 1996: 57).

In the text, Al-Tahawi gives us an example of forcing Bedouin women to marry men they do not want. Safyia, according to Bedouin customs, marries her cousin and no one cares about her opinion or rejection because she is a woman. Women do not have a voice in Bedouin society. Safyia refuses to polish her hands and feet with henna, as a Bedouin tradition and expresses her rejection of this marriage because it does not match what she wants, But she faces the power of the patriarchal community by the words of her grandfather: "You belong to your man now, you miserable creature. And since when do you think you've any say in the matter, you piece of camel dung! "(Al Tahawi, 1996: 57).

She faces a series of insults and devaluation when she refuses to marry her cousin and is confirmed that she is a property of her husband and will be his home. Safyia is confronted with the idea that her voice is never heard and no one cares her opinion. Safyia as a Bedouin woman must obey the patriarchal Bedouin traditions silently and accept what the masculine authority views appropriate to support patriarchal society.

Control of women in patriarchal societies goes beyond its limits in the enslavement of women by enacting laws that restrict women from visiting their homes. The women who do so have violated patriarchal values, and the husband must be more strict and cruel to his wife so that they proceed on the basis of patriarchal norms:

That man of yours is head over heels in love with you, you wicked girl. I tell you, the only thing that will work with you is a stick. Your husband's full of nonsense, and he's still after you. If he was a real man, he would drag you home by the hair (Al Tahawi, 1996: 71).

Safyia is subjected to scolding and insulting because she visits her parents' home to pay attention to her sick mother. Her grandmother describes her husband as not a real man because he leaves his wife to visit her parents' house. The real man according to Bedouin 
standards is one who is strict and cruel in dealing with his wife. The grandmother adds that her husband should take her home by force. Through the words of the grandmother is clear to us the status of the wife in the Bedouin community, where she is exposed to violence and deprived of the most basic rights as a visit to her parents' home. Hence, al-Tahawi also reveals to the reader that the husband's leniency with his wife is considered to be defective according to the Bedouin custom. The man must be strict, strong and violent in his behavior with his wife. Speech in the text issued by the family of the girl and this is evidence that everyone agrees on the abuse of women.

Through the reading and analysis of texts, the status of Bedouin women under the Bedouin patriarchal rules is completely collapsed. Bedouin women are subjected to systematic oppression that makes them acquire patriarchal values that keep them subordinate and inferior to men since childhood. Through the child Fatima, we witness the strict patriarchal values that are applied to her to produce a negative woman who does not realize her right and dedicates her life to serve the masculine rules and values. Women's voices and their right to express their views or what they desire are stopped in favor of masculine authority. Those patriarchal provisions and rules that violate the right and freedom of women, maintain and perpetuate masculine power by making women fully subordinate to men.

\subsubsection{The Mother}

The character of the mother in Al-Tahawi's novel The Tent embodies much of the suffering of Bedouin women experience humiliation and psychological abuse. The mother suffers psychological defeat and community restrictions placed by the community around her for giving birth to girls. The Bedouin society wants this mother to give birth to males to support and empower male domination. The mother is marginalized by her husband and grandmother because of her frequent births to girls. She is treated harshly and subjected to insults, verbal abuse, and deliberate neglect. The mother wrestles with her desire to give birth to a male to restore dignity and the loss of males as soon as give birth to them, which brought her misery and ill-treatment and humiliation by the others:

God's will or the touch of the Devil. That woman's brought nothing but disaster since the day she came. Every time God gives her a boy, he gets taken away. And she's deranged. I fear for my soul when I see her having those fits. It's an evil omen (Al Tahawi, 1996: 63).

The patriarchal oppression of this mother is a quotation put forward by Al Tahawi to reveal the status of women under the constraints of the Bedouin community. In the text, the grandmother describes the mother as bringing the only disaster to the house. Girls according to the Bedouin concept do not give any value to the family, but they are a disaster. The grandmother directs on a series of words of humiliation and contempt that make the mother suffer a psychological breakdown and pain because of the insults and wounding her dignity that she encounters every day. The mother is dealt with by the father and the grandmother as if she was nothing. Women have to give birth to males, so she takes some respect.

Therefore, the mother lives in a state of surrender and submissiveness and complete humiliation, she is considered in the eyes of patriarchal authority as guilty of the right of society and deserve to receive hostility from all around: "This waste the stuff on her! She's given birth to nothing but bad luck"(Al Tahawi, 1996: 9). 
In the statement above, the grandfather incites to abuse the mother as a woman who does nothing to the family other than bad luck "girls". Women in Bedouin patriarchal societies are often treated as male production machines to help increase their number with non-stop. In The Tent, although all males die when they burn, the mother continues to reproduce, perhaps the male lives. Women here, give up their personal interest, attention to themselves, health and psychological condition for the happiness of men and to their desire to increase in the number of males.

Are you sleepy, mother? She didn't answer, but I saw her swollen eyes staring at me. Why are you crying? (Al Tahawi, 1996: 20).

The mother, in Miral al-Tahawi's novel, symbolizes the Bedouin mother who suffers from society' view as inferior and humiliated women, since the death of her male infants. The mother is living in a state of refraction, marginalization, and neglect by others. This leads to the destruction of her psyche and the psychological pain she suffers silently. The mother cries silently and away from the eyes of others because she feels guilty of the right of society and the family. She lives in a state of loss and a sense of disrespect. Everyone accuses her of being a woman who brings bad luck and does not deserve recognition. A woman does not give birth to males in the patriarchal Bedouin society, leading her to live marginalized and humiliated.

We conclude from this, that the mother in the novel Miral Tahawi, treated by members of the patriarchal system as a tool to produce males to strengthen the masculine authority. She is humiliated and ridiculed and fought psychologically because she cannot do what the male wants. Bedouin woman " the mother" in the novel is seen completely submissive and resigned to her fate as an inferior or less value in the community She cries silently because she cannot do what her husband wants and because she is mistreated to the point of ignoring her, she tries to keep attempting to make her husband happy, but she only receives contempt.

\subsection{Female characters of AlTahawi and Radical Feminism}

The Radical Theory of Feminism strongly emphasizes that patriarchy is the basis for the oppression of women in societies. Radical Feminism believes that imposing a model of domination of women in society comes through masculine authority and power. In this study, the concept of Radical Feminism was studied from the analysis of the text of Miral Al Tahawy through the use of the concepts of patriarchal oppression applied to female characters. The status of the female characters has been embodied as subordinate, subjugations, or rejecting in silence. This study reaches the conclusion that the concepts adopted by radical feminist are used in the embodiment and depiction of patriarchal oppression of women, especially the concepts of masculine authority, domination, and power. Miral Al Tahawi reveals her female characters such as the grandmother Hakima, Fatima, Safia, and the mother are controlled by the masculine power completely and forced to acquire the patriarchal values that make them submissive and surrender to those values.

The female characters in Miral Tahawi's novel are oppressed by the masculine authority, which is considered as the centerpiece of Bedouin society. Fatima and Safia are deprived of their most basic rights, such as going out of the house, playing, singing, trying to mix with others, or even their right to choose a life partner. Patriarchal rules are applied to them without thinking about their feelings or how these rules will affect their psyche. The mother is subjected to isolation, neglect, and humiliation by the husband and grandmother, without having any consideration to her feelings as mother loses her children after birth or as a 
woman has the right to decide her right to have more children or no. All his female characters are victims of man's obsession with control, and they know their status under that patriarchal oppression. Fatima's thought of escaping by climbing the tree and Safia refusal to marry is an awareness of their tragic situation under the patriarchal oppressive system. The silence of the mother and her surrender to the isolation and neglect that she put by her husband and grandmother is subject to patriarchal orders and values. Her cry and tears silently may tell us that she is aware being exploited by that patriarchal authority, but the mother often puts her husband's interest and happiness before her own and therefore continues to give birth to the males who die as soon as come to life.

Miral Al-Tahawi presents her female characters under the patriarchal oppressive system as being vulnerable to violations of personal and public rights and freedom of thought and opinion. She develops her female characters through the attempts of some characters to rebel against the patriarchal values such as the refusal of Safia to marry her cousin or Fatima's attempt to escape by climbing the tree and losing her foot. From hence, Al Tahawi makes the reader discover the plight of Bedouin women at the end of the 20th century, rethink of the social and cultural norms imposed on Arab women and Bedouin women in particular, and try to challenge and reject patriarchal practices and rules that have long restricted Bedouin women. The study also reveals to us the spirit of rebellion within women that will make a change if they find support to save and free them from patriarchal restrictions. Therefore, Al Tahawi supports the idea of radical feminism to challenge the patriarchal oppression and discrimination against Bedouin women by the masculine authority.

\section{Conclusion}

Asa conclusion, the female characters of Al Tahawi are oppressed because of patriarchal authority, which is viewed men as the center of the patriarchal system. Fatima, Safia, and the mother are oppressed through the restrictions imposed on them and control their fate, marginalization, and isolation. The masculine authority uses force against women to protect its power and dominance in the home and society. Thus, women become victims and submissive to men who use them for their own interests. Women are imprisoned so as not to mix with the outside world, therefore, Fatima tries to escape, which cause her to lose her leg. Safia is forced to marry by force without paying attention to her personal feelings or opinion. The mother is marginalized, isolated and ignored because she does not achieve the desire of her husband to give birth to males. Miral Al Tahawi does not forget to reveal to us how some of the characters are raised on and stereotyped to these values and becomes a tool in the hands of masculine power to oppress other women like the character of the grandmother Hakima. Besides, Al-Tahawi shows us that there is a spirit of rebellion in some of the characters through the refusal of Safyia to marry or Fatima's attempt to escape or even the mother's cry, which is a silent rejection to what she faces of patriarchal oppression and cruelty. Al Tahawi uses these female characters to expose the rebellious spirit of Bedouin women and thus to strengthen their identity to challenge the patriarchal oppressive system.

\section{References}

Al Tahawi, M. (1996). "The Tent" American University in Cairo.

Bennett, J. M. (2006) History matters: patriarchy and the challenge of feminism. Philadelphia: University of Pennsylvania Press. 
Frederick, D. (1992)." Radical Feminism: An Expose: Liberation Alliance. P, 1-5-18.

French, M. (1983). " The Politic of Reality: Essay in Feminist Theory. California: the crossing press. P, 239.

Kreps, B.(1970.) "Radical Feminism" in Feminist Theory Reader: Local and Global Perspective. Newyourk: Routledge.p, 45-49.

Millett, K. (1970). "Theory of Sexual Politics" In Radical Feminism: A Documentary Reader. Ed. Barbara Crow. New York: New York University Press. P,26-55.

Millett, K. (1977). Sexual politics. Garden City, N.Y.: Doubleday. Mandell, N.1995. "Feminist Issues: Race, Class, and Sexuality" Prentice Hall Canada, Inc.Ontario, p.4-35.

Rhodes, J. (2005)." Radical Feminism, Writing and Critical Agency: From Manifesto to Modern. New York: Albany, State University of New York Press. P. 4.

Joseph, S. (1993) Connectivity and patriarchy among urban working-class families in Lebanon,' Ethos 21: 4. 